Int. J. Plant Sci. 177(7):618-632. 2016. (C) 2016 by The University of Chicago. All rights reserved.

This work is licensed under a Creative Commons Attribution 4.0 International License (CC BY 4.0), which permits reuse of the work with attribution. 1058-5893/2016/17707-0006\$15.00 DOI: 10.1086/687301

\title{
SPORANGIAL MORPHOLOGY OF THE EARLY DEVONIAN ZOSTEROPHYLL SAWDONIA ORNATA FROM THE TYPE LOCALITY (GASPÉ)
}

\author{
Patricia G. Gensel ${ }^{1, *}$ and Christopher M. Berry† \\ *Department of Biology, University of North Carolina, Chapel Hill, North Carolina, USA; and +School of Earth \\ and Ocean Sciences, Cardiff University, Wales, United Kingdom
}

Editor: Michael T. Dunn

\begin{abstract}
Premise of research. Despite being an iconic and recognizable zosterophyll from the Early Devonian, sporangia of Sawdonia ornata are not known in any detail from the type locality, being represented by a drawing and a few illustrations from other localities. This has hampered recognition and/or comparison of other zosterophylls or newly discovered plants to that taxon. A detailed study of sporangia obtained from axes of $S$. ornata from the type locality was conducted to investigate sporangial morphology and range of vegetative features.
\end{abstract}

Methodology. Fertile specimens were prepared by dégagement and maceration to expose both vegetative and reproductive features more fully than previously. Maceration produced axes and sporangia that were examined by LM and SEM.

Pivotal results. Sporangia of $S$. ornata from the type locality consist of unequal valves: a larger and more rounded outer/abaxial valve-in which the stalk merges imperceptibly with the back of the valve and both are covered with spines - and a smaller, thinner, and flat inner/adaxial valve that lacks spines. Each valve has a narrow flat rim not readily visible unless the sporangium is open. The sporangia are located near and well below the apex of aerial stems and may be located on one or two sides of the stems, with the sporangia being curved in toward the stem and slightly around it, mostly at a slightly acute angle to the stem. Variation in density and angle of lateral branching within a pseudomonopodial system is also demonstrated. A new reconstruction of the sporangia is provided.

Conclusions. The new data on sporangial morphology from type locality specimens provide a clear set of characters delimiting $S$. ornata, type for the genus, and require that the taxonomic circumscription of $S$. ornata be emended. This in turn affects identification of closely similar taxa, such that some are excluded from the genus, others are questionably attributed to Sawdonia as cf. Sawdonia sp. These differences are considered significant enough to recommend placing Sawdonia acanthotheca Gensel, Andrews, and Forbes in another genus and to rename Ensivalia deblondii Gerrienne as a new combination, Sawdonia deblondii (Gerrienne) Gensel et Berry. Sawdonia is the third zosterophyll taxon to demonstrate sporangia with unequally sized valves and, more intriguingly, little differentiation between stalk and distal valve. These results will allow more accurate comparison of other zosterophylls to this genus in terms of reproductive characters and assessment of diversity in zosterophylls than previously. It is less clear whether a certain set of vegetative-particularly cuticular-features continue to allow one to recognize this taxon from fragments.

Keywords: Sawdonia ornata, sporangial morphology, type locality, genus and species delimitation.

\section{Introduction}

Sawdonia ornata Hueber (1971) is one of the most iconic and recognizable early land plant taxa that holds an important place in both plant systematics (Banks 1968, 1975; Kenrick and Crane 1997) and early land plant ecology (Hotton et al. 2001). It has been studied since Dawson's recognition of the existence of Psilophyton princeps var. ornatum, on the basis of the discovery of large numbers of branching spiny axes in a bed of gray sandstone on the north shore of Gaspé Bay, Quebec, Canada

1 Author for correspondence; e-mail: pgensel@bio.unc.edu.

Manuscript received February 2016; revised manuscript received April 2016; electronically published July 19, 2016.
(Dawson 1871), and is regarded as one of the key taxa of Zosterophyllopsida. Similar axes are geographically and stratigraphically widespread, and the concept of the species has subsequently evolved on the basis of limited evidence from the type locality (Edwards 1924; Lang 1931: cuticle) but mainly from other Early Devonian (Emsian) localities in Canada (Hueber 1992: Abitibi River, sporangia), Scotland (Rayner 1983: anatomy, cuticle, fertile region) and Siberia (Ananiev and Stepanov 1968: sporangia, overall reconstruction). Despite this, sporangia and habit of S. ornata from the type locality have never been described and illustrated. This has hampered both recognition/ confirmation of the genus and species in other localities, taxonomic assignment of new fossils that share many of the simple characters regarded as typical of Sawdonia, and paleophytogeographical analysis. 
We have located and studied more than 30 fertile specimens of $S$. ornata from the type locality in Gaspé. Our new data demonstrate both known and until now unrecognized features of the sporangium in regard to its shape, comparative valve size and organization, emergences, mode of attachment, and distribution on stems. These and additional apparently vegetative specimens demonstrate branching patterns and cuticular features (Gensel et al. 1990). Together, these specimens allow a more precise diagnosis of the genus and new assessment of the systematic position of related taxa.

\section{Previous Descriptions of Fertile Remains Referred to Sawdonia ornata}

Hueber (1964) presented information on-but no photographic evidence of - sporangia of $P$. princeps var. ornatum Dawson 1871 from Abitibi River, northern Ontario, Canada, ca. 500 miles from the type locality. He amplified his words with a drawn reconstruction showing globose naked sporangia inserted laterally on a short stalk on spiny axes. Although only one valve is visible in the drawing, the position of the dehiscence line suggested that the sporangium was equivalved. He further stated that specimens subsequently obtained from the type locality in Gaspé were "identical in form and arrangement with those from the Abitibi River site" (Hueber 1964, p. 8).

Hueber and Banks (1967) clarified the difference between $P$. princeps Dawson, with terminal paired fusiform sporangia, and the now clearly morphologically distinct $P$. princeps var. ornatum. They repeated only the line drawing interpretation of the fertile axis of $P$. princeps var. ornatum on the basis of Abitibi River material. They also illustrated the anatomy without stating the locality from which it was obtained.

Hueber (1971) formally renamed P. princeps var. ornatum as $S$. ornata (Dawson) Hueber. Of those specimens from Dawson's original illustrations (Dawson 1871, pl. IX, figs. 97101), Hueber could find only one specimen in the Redpath $\mathrm{Mu}-$ seum (fig. 101; Redpath Museum 3243) and designated it as the type specimen (our fig. 1). Two other specimens from Dawson's type illustrated collection now reside in the Natural History Museum (London): figure 100, NHMUK PB V 14918, and figure 97, NHMUK PB V 13233. Hueber's designated type is a short length of sterile spiny axis showing a circinate tip and a small lateral protrusion that we believe to be a small bud. Hueber provided no new illustrations.

Hueber's generic diagnosis (1971, p. 642) states that the sporangia are "round in abaxial view, oval in lateral view, borne laterally and singly on short stalks" and that the dehiscence is "basipetal and complete, splitting along convex margins into equal valves." No evidence for this was provided from the type locality. Hueber (1992, fig. 3A, 3B) figured an axis of $S$. ornata from Abitibi River with suboppositely paired naked sporangia and a detail of one of these pairs showing a dark strand extending into the stalk. He also illustrated a vegetative specimen (1992, fig. 3C), believed to be from the Gaspé locality, with lateral buds that could easily be mistaken for sporangia if not examined closely. Currently, these buds are considered to represent undeveloped lateral branches.

Ananiev and Stepanov (1968) described specimens - using the name $P$. princeps as it was used by White (1905) and Halle (1916) but corresponding to the concept of $S$. ornata of Hueber

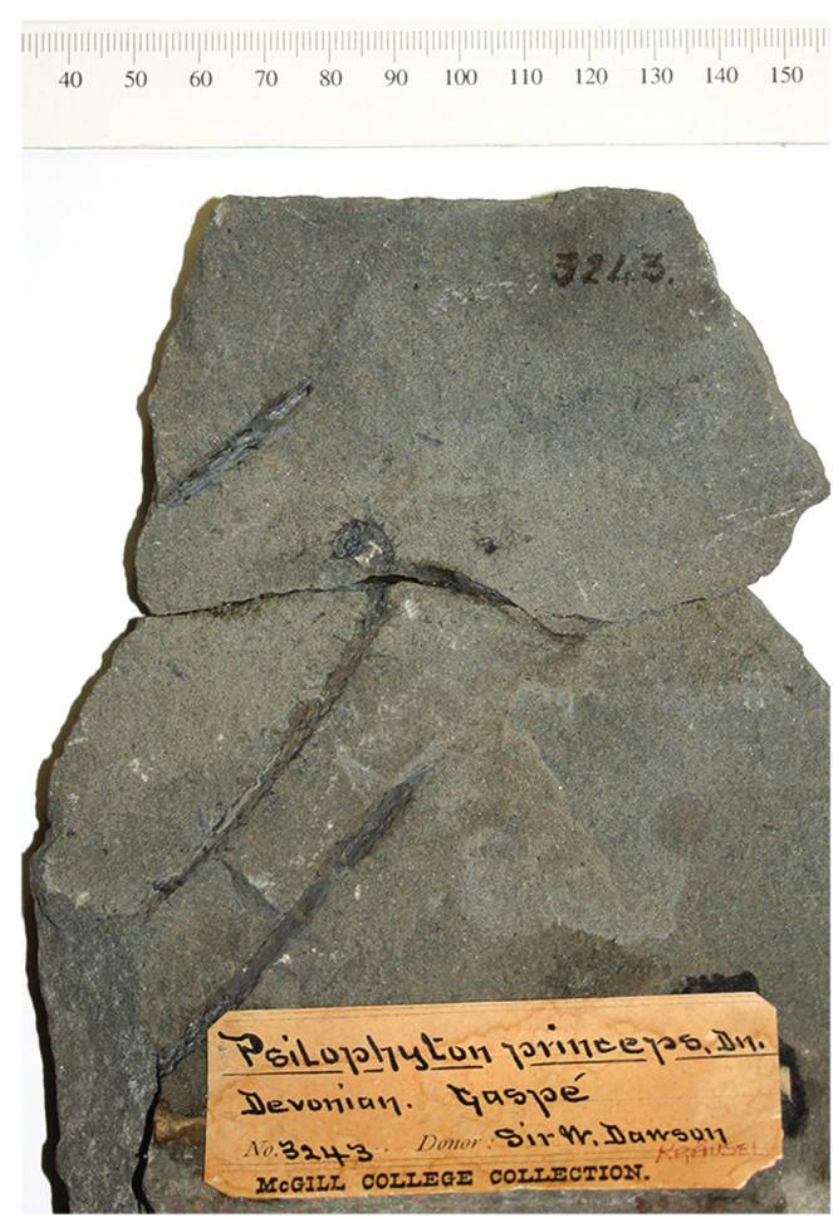

Fig. 1 Type specimen of Sawdonia ornata from the type locality, Cap-aux-Os, Gaspé, designated by Hueber (1971). Redpath Museum specimen 3243. Image courtesy of Anthony Howell, Redpath Museum. Image included with permission of the Redpath Museum, McGill University.

(1971) — from the Early Devonian of Minusinsk, Siberia. Several fertile specimens provided the basis for their general description of the sporangia, and most were figured at a low magnification. Notable in their illustrations and descriptions of sporangia is the presence of a distinct stalk. The implication of their description and reconstruction of the fertile region (their fig. 7) was that the sporangia were imperfectly rounded and that they split open into two valves. They produced a reconstruction of the fertile region and of the whole plant, on the basis of all their evidence, which has subsequently been highly influential.

General views and a description of $S$. ornata sporangia borne in two rows near tips of stems were presented by Rayner (1983), on the basis of specimens from the Early Devonian Strathmore Group, Scotland. The preservation did not allow for detailed description of sporangia. He also described spores obtained from the sporangia, epidermal features, and stem anatomy.

Gensel and Andrews (1984, fig. 4.47) figured a compression specimen from the type locality with a row of five probable sporangia attached to a spiny axis. Gensel et al. (1990) and Gensel (1992) figured a sporangium isolated from the type locality 
matrix by maceration, which demonstrated that at least one valve bore spiny emergences, although the locality was not specified in either publication. In summary, sporangial morphology and attachment in the taxon $S$. ornata has been described only in very general terms, and accounts are not consistent on the basis of these different publications from various localities.

\section{Material and Methods}

Specimens of Sawdonia ornata were collected from the type locality on the north shore of Gaspé Bay, which is part of the Cap-aux-Os Member of the Battery Point Formation, located east of Gros Cap-aux-Os and near D'Aiguillon. This is locality $S$ in Gensel and Andrews (1984, table 12.2) and at 10.4$11.0 \mathrm{~m}$ of the $\log$ of the Cap-aux-Os member presented by Hotton et al. (2001, fig. 11.3). Dispersed spore data place the sediments as part of the annulatus-sextantii spore zone of Richardson and McGregor (1986) and thus early late Emsian in age. Griffing et al. (2000) and Hotton et al. (2001) suggest - on the basis of the presence of a basal underclay and waxy claystone followed upward by a mat of axes and then several additional layers of curved axes in coarser sediments-that $S$. ornata was buried during several crevasse-splay flood events, with sediments prograding into the flood basin and burying the plants. There is some evidence that these plants were growing near a shoreline. The present Gaspé specimens are preserved in a greengray fine-grained sandstone from the mid- to upper part of the Sawdonia horizon. More than 30 specimens in the University of North Carolina-Chapel Hill (UNC-CH) collection from the type locality - preserved as adpressions - were found to bear at least one sporangium and some exhibit several (figs. 2, 3). Fertile specimens were subsequently identified in the Cardiff University collection of Gaspé material. All figured specimens are from the UNC-CH collection and will be deposited in Geological Survey of Canada collections with the following numbers: GSC 138210-138230.

Fertile and nonfertile specimens were prepared via dégagement (Fairon-Demaret et al. 1999), including serial dégagement, with photography at each stage. Selected specimens were macerated following standard $\mathrm{HCl}$, HF protocol (Gensel et al. 1990; Wellman and Axe 1999), releasing fragments of axes, some with attached sporangia. Macerated specimens were either dry mounted or cleared in Schulze's solution and mounted on slides with CMCP mounting medium. Specimens obtained from maceration were also mounted on stubs and examined with an FEI XL30 ESEM FEG microscope (Cardiff). LM images were taken with a Wild photomakroskop (NC) or Leitz Aristophot and Nikon D300 camera (Cardiff) and processed using Adobe Photoshop CS 6. Important to this study is the fact that maceration followed by LM or SEM study of several specimens has provided valuable information on critical morphological features not readily visible on specimens still in the rock matrix.

\section{Results}

\section{Fertile Specimens}

Axes exhibiting one or more lateral sporangia have much less densely spaced emergences than vegetative axes (figs. 2, 3). Axis width is $1.6-2.6 \mathrm{~mm}$ in regions between attached sporan-
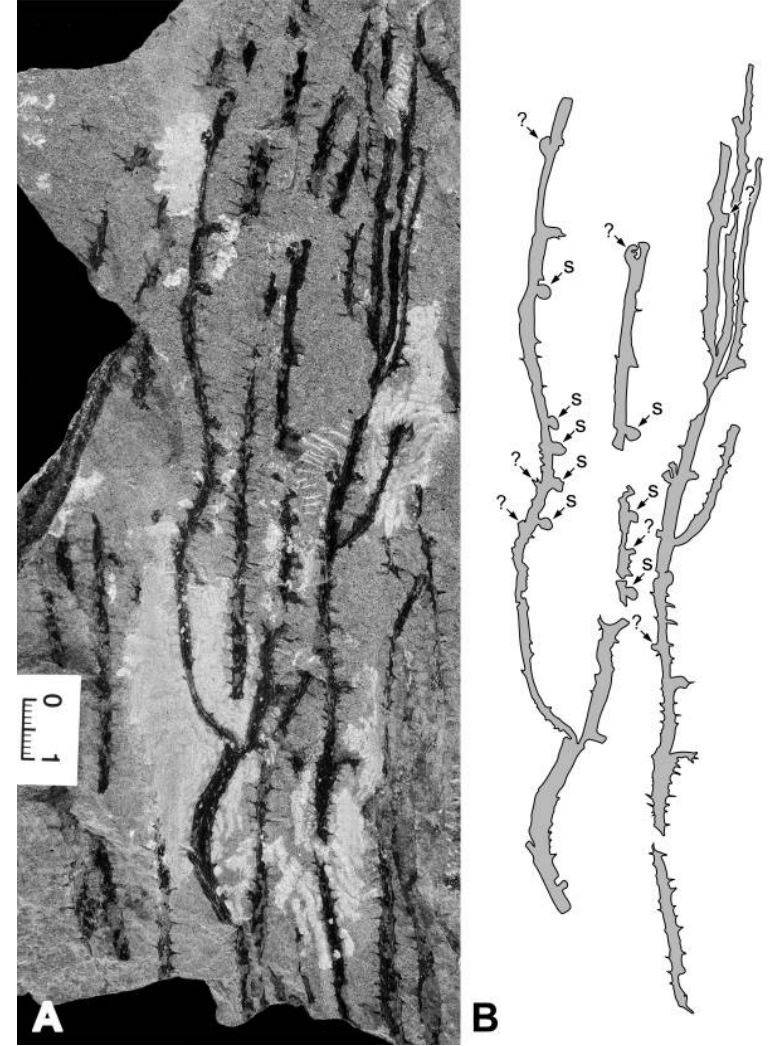

Fig. 2 Fertile specimens of Sawdonia ornata from the type locality, Cap-aux-Os, Gaspé. A, Large specimen of S. ornata from the type locality, Cap-aux-Os, Gaspé, showing numerous sporangia apparently not restricted to distalmost axes. $B$, Line drawing of the two axes bearing sporangia (s) or sites of possible sporangia (?). Sporangia occur apparently some distance from the apex. Note branching in the two individual plants. Right-hand branch of left plant shows discontinuities, but there is strong evidence that those were originally connected. Scale bar $=1 \mathrm{~cm}(A)$. GSC 138210 .

gia. The sporangia sometimes appear to occur on one side of the axis, but some specimens indicate they are either subopposite in two rows or spiraled (figs. 2, 3, 4B). Some are located just beneath a circinately coiled apex (fig. $3 B, 4 H$ ), while others occur some distance below the apex, on the basis of the number visible along the several times branched axis (fig. 2). Sporangia are positioned $1.5-7 \mathrm{~mm}$ apart. In regions where sporangia are widely spaced, it is probable that additional sporangia occur but are not exposed. This is supported by the specimen figured in figure 2, where visible sporangia occur only on one side of the axis but there are stubs indicative of a structure departing alternately to the other side. In other specimens, sporangia are often clearly visible on opposite sides of the axes (fig. 3B).

The fertile organ of Sawdonia ornata comprises a curved stalk and two valves (figs. 3-7). The sum of evidence from the type locality presented below demonstrates that one valve (abaxial) is large and deeply convex and incorporates the end of the stalk and that the other (adaxial) is smaller and flatter. Both the stalk and the abaxial valve are spiny and are rarely, if ever, preserved upright. Where determinable, the sporangia examined for this study appear to be dehisced. 


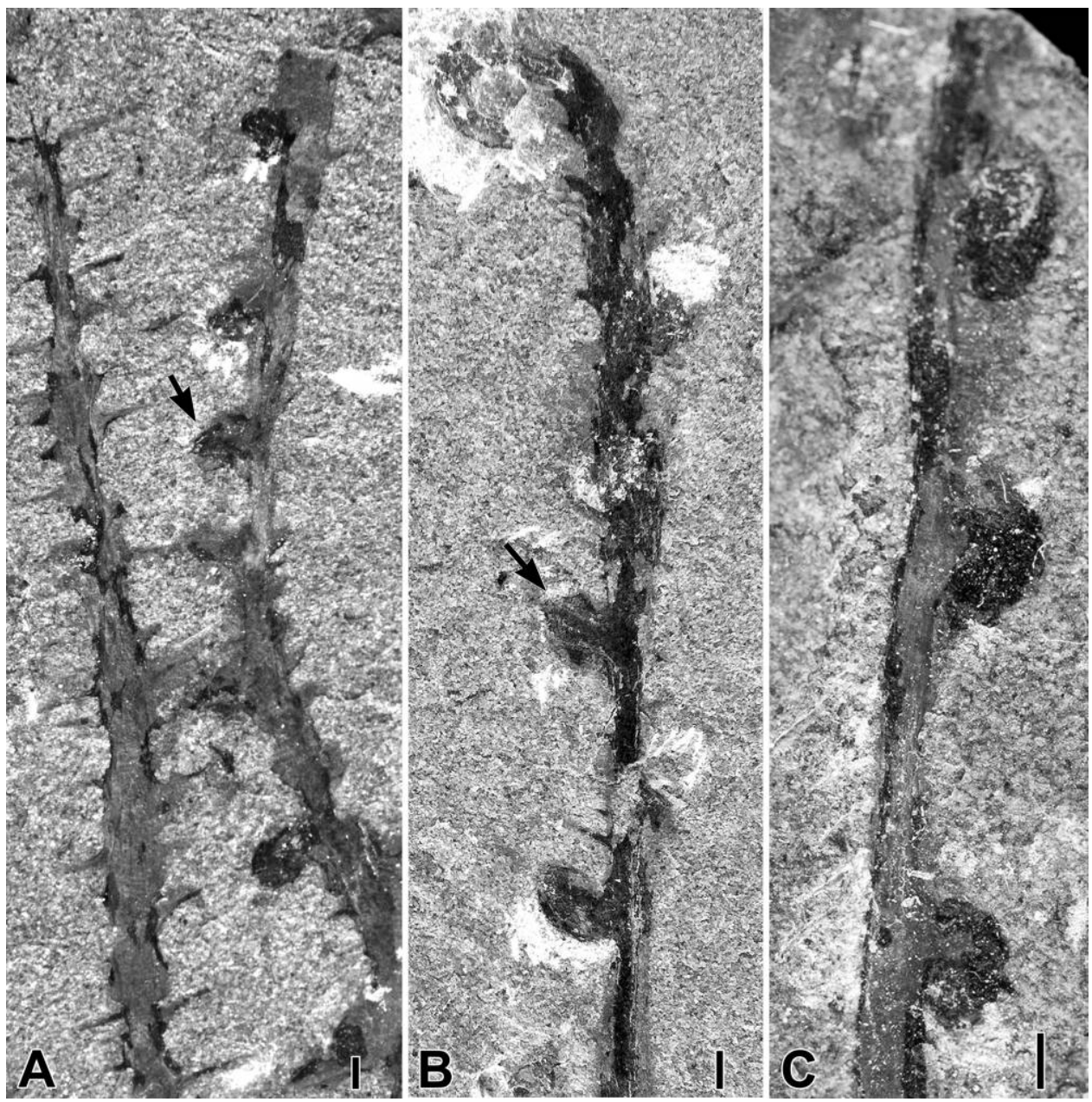

Fig. 3 Fertile specimens of Sawdonia ornata from the type locality, Cap-aux-Os, Gaspé. Sporangia-bearing regions of three separate axes. A, Counterpart to midregion of axis on the left in fig. 2. Arrow indicates sporangium borne at acute angle to axis. GSC 138210. B, Axis with crozier at top; sporangia occur very close to the tip, but top two are poorly preserved. Arrow indicates sporangium borne at acute angle to axis. GSC 138211. C, Sporangia mostly bent down into matrix, stalk not readily visible; note part of spine on adaxial valve of lower sporangium. GSC 138212. Scale bars $=10 \mathrm{~mm}$.

Interpretation of sporangial morphology is aided by recognition of the dehiscence margin of one or both valves. In compression fossils and macerated specimens, this appears as a narrow $(50-70 \mu \mathrm{m})$ strip of flat carbon that is visible only on the inner view of a valve (figs. $5 A, 6 A$ [arrow], 6B, 6E, 7 [black shaded area]) and superficially appears folded inside it. In the living sporangium, this flat area of contact between the two valves would not have been visible or would have been represented as a groove or depression marking the zone of forthcoming dehiscence.

Sporangia are approximately 1.4-3.4 mm long (measurement parallel to the stalk) and 1.7-4 mm wide (measurement perpendicular to stalk). They are borne on stalks $1.5-2 \mathrm{~mm}$ long and 1-1.5 mm wide (figs. $3 A, 3 B, 4 A, 4 B, 4 D, 5,6 A, 7$ ). Many sporangia are only partially visible, folded, or very distorted (figs. 3C, 4B, 4C, 4E, 4H), such that accurate measurements for several could not be obtained. Very few stalks are visible enough to measure.
Considerable variation in the angle of stalk departure and sporangial orientation exists, as follows. (1) In a few specimens, sporangial stalks depart from the stem at an acute angle and are directed upward, with the sporangium extending directly from it so it appears upright and more or less appressed to the axis, similar to Hueber's 1964 reconstruction (figs. $4 A$, $6 \mathrm{C}, 6 \mathrm{D})$. (2) In many, the stalk departs at an angle of $50^{\circ}-80^{\circ}$ to the side of the stem, and the sporangium extends straight out at the same angle (figs. $3 A, 3 B$ [arrows], 4C, 5, 6A, 6B, $6 F, 7)$. (3) Other sporangia appear to exhibit a stalk oriented perpendicular to the stem, with the sporangium extending straight out from the stem (fig. $4 D, 4 G$ ). In a few of these, sporangial valves are folded lengthwise (fig. $4 H$ ). Sometimes the sporangium is folded or preserved such that the inside of the valve is visible (figs. $4 H, 6 E$, both the same specimen). (4) Several sporangia that are oriented at acute or right angles to the axis exhibit the abaxial valve bent downward or crushed sideways against the stalk, covering the adaxial valve, which itself is 

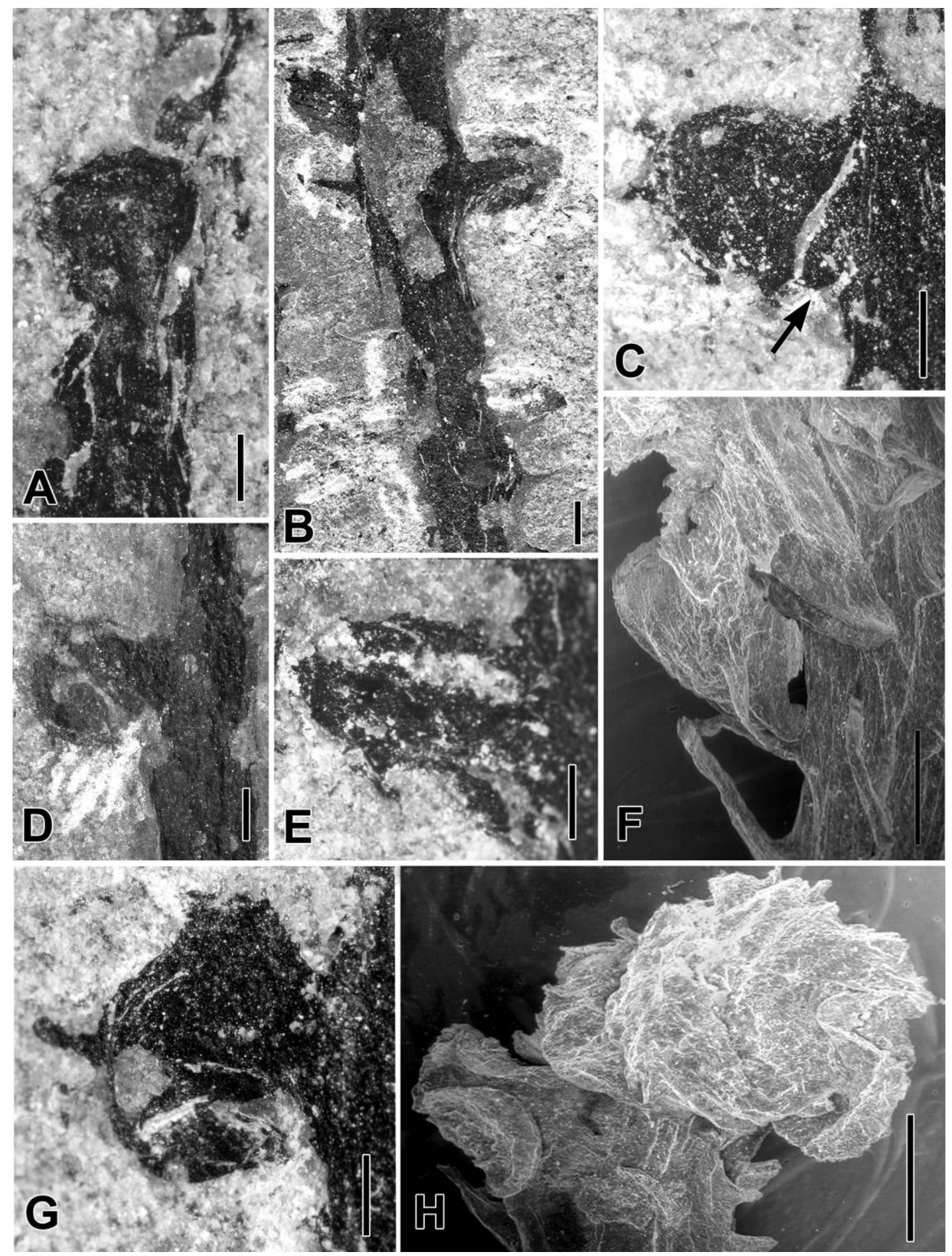

Fig. 4 Fertile specimens of Sawdonia ornata from the type locality, Cap-aux-Os, Gaspé. LM and SEM of sporangia showing variation in orientation and position. A, Sporangium appears upright. GSC 138213. B, E, Sporangium oriented at right angles to axis, folded down onto stalk, stalk side uppermost. B, GSC 138214. E, GSC 138213. C, Folded sporangium from adaxial side, oriented at slight angle to axis. Note adaxial valve at arrow. GSC 138213. D, G, Two views of sporangia, oriented perpendicular to axis, with adaxial valve foremost. Note spine on abaxial valve in $G$. $D$, GSC 138215. G, GSC 138216. F, SEM of axis with sporangium axis departing perpendicular to axis, then bending upward. Part of folded nonattached sporangium above. $H$, SEM of sporangium with valves folded parallel to stalk, located just below a crozier. Scale bars $=10 \mathrm{~mm}$. 

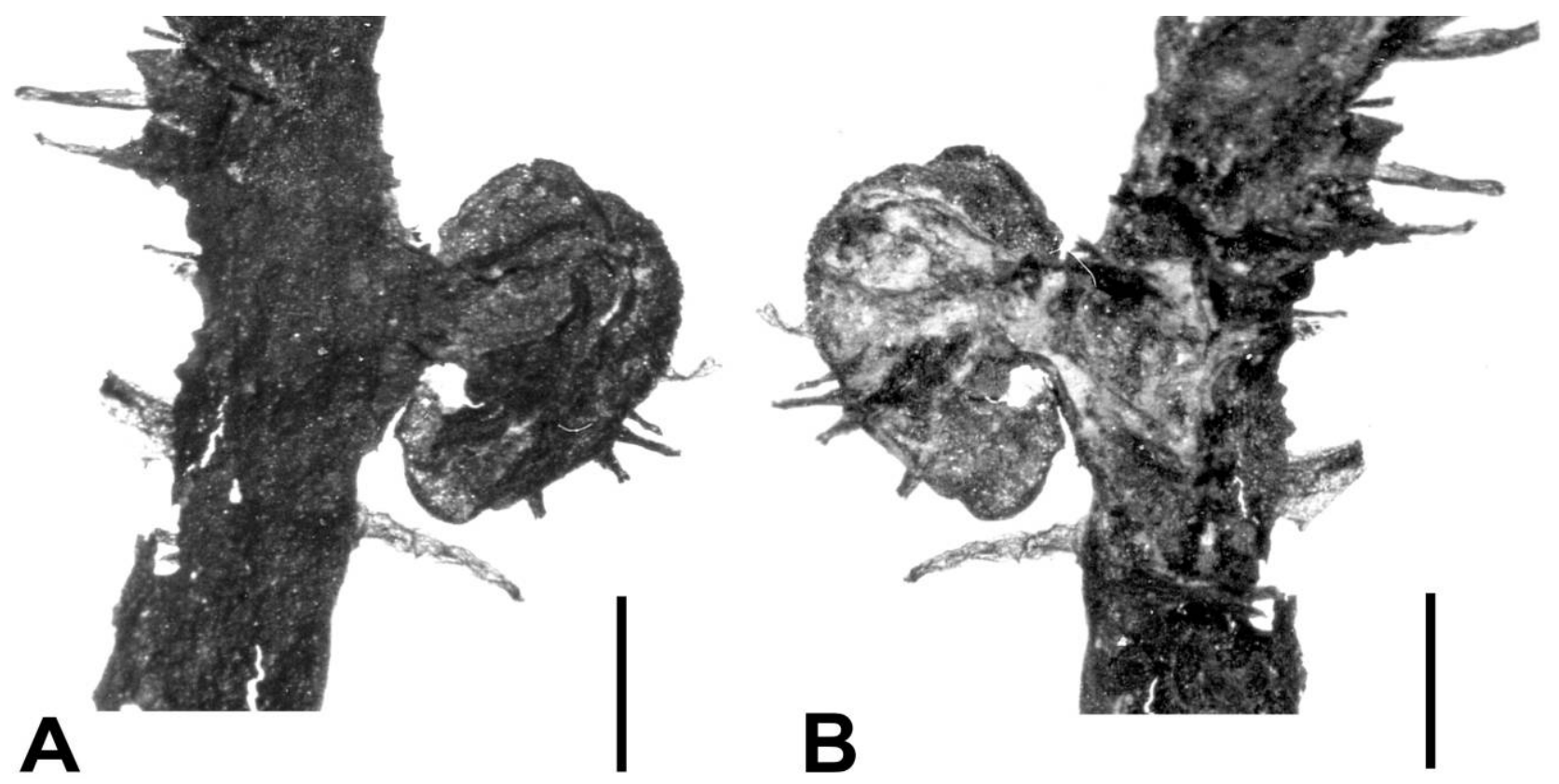

Fig. 5 Fertile specimens of Sawdonia ornata from the type locality, Cap-aux-Os, Gaspé. Sporangium-bearing axis isolated by maceration (for matching line drawing, see fig. 7), designated herein as the epitype. A, Specimen oriented with smaller, folded, and broken adaxial valve uppermost. Note narrow rim and spines on abaxial valve. $B$, Specimen oriented with abaxial sporangium valve uppermost; note stalk extends onto valve, abaxial valve and stalk with spines. GSC 138217. Scale bars $=10 \mathrm{~mm}$.

pressed against the stalk (figs. 2, 3B, 3C, 4B, 4C, 4E, 6A, 6B, 7). (5) In others, the stalk departs at a right angle and then turns upward (fig. $4 F$ ).

The variation in orientation and angle of view may lead to some of the perceived variation in sporangial shape or size in these specimens. When sporangia are viewed abaxially in this material, their shape is usually rounded. In specimens where the stalk and sporangium wrap around the stem or bend down into the matrix, only the outer edges are visible, and shape and size cannot be determined (figs. 3C, 4B, 4C, 4E, 6A, 6B, 7).

The abaxial valve is larger and more convex than the adaxial one (figs. $5 B, 6 C, 6 F$ ), and it is covered in spine-like emergences that range in length from 0.3 to $0.8 \mathrm{~mm}$ (figs. $4 \mathrm{G}, 5,6 \mathrm{~A}, 6 \mathrm{~B}, 6 \mathrm{D}$, $6 F)$, with some being incomplete. The longest complete one is $0.8 \mathrm{~mm}$. The sporangial stalk, also with emergences, extends onto and merges inconspicuously with the abaxial valve (figs. $5 B, 6 A)$. LM and SEM images also suggest that there is little distinction between the basal region of the adaxial valve and its stalk (figs. 4D, 4G, 5A, 6F).

In a well-preserved example, isolated by maceration (fig. $6 A$, $6 B)$, examination by binocular microscope has allowed mapping of the valve margin. This is visible on the inner surface of the valve on both sides (fig. $7 C, 7 C^{\prime}, 7 D, 7 D^{\prime}$ ), and its position can be inferred from the sharp edge where the inner surface of the valve is obscured by the stalk (fig. $7 C, 7 C^{\prime}$ ). The resulting composite of the abaxial valve suggests that it has been both crushed and pushed upward along the stem (fig. $7 C^{\prime}$, $\left.7 D^{\prime}\right)$ and that the margin is relatively long, starting close to the stalk on either side. The margin of the abaxial valve is also seen in another specimen (figs. $5 A, 5 B, 7 A, 7 A^{\prime}, 7 B, 7 B^{\prime}$ ), where it is continuously visible on one side.
The adaxial valve frequently lies inside the abaxial one and is clearly smaller and thinner and lacks emergences (figs. $4 C$, $4 G, 5 A, 6 C, 6 F)$. A few spores were found adhering to the inside of opened sporangial valves; these are round and smooth (fig. 6G).

\section{General Morphology of Sawdonia ornata}

The fertile axes-and those axes in this collection that lack sporangia - exhibit external morphology and cuticular features that compare well with the limited previous descriptions from the type locality (summarized next) and the generic and specific diagnoses relating to sterile characters (Hueber 1971). Three of Dawson's original figures of Psilophyton princeps var. ornatum (1871, figs. 97-99) show branching of apparently sterile axes, where it appears to occur at approximately $2-5-\mathrm{cm}$ intervals (on the basis of our interpretation), but he did not describe this aspect of morphology. There are no subsequent clear descriptions of branching from the type locality.

More recent information on external morphology from the type locality consists of one or a few axes with almost no branching evident (Edwards 1924; Hueber and Banks 1967; Gensel et al. 1975; Gensel and Andrews 1984). Cuticular features have been well documented for $S$. ornata from the type locality by Edwards (1924), Lang (1931), Gensel et al. (1990), and Gensel (1992). Similar cuticles, identified as $S$. ornata, have been described from localities in Scotland, southern England, New Brunswick, Canada, and Poland (Lang 1932; Zdebska 1972; Chaloner et al. 1978; Edwards et al. 1982, 1998; Rayner 1983; Gensel et al. 1990, fig. 11E, 11F; Edwards 1993). 


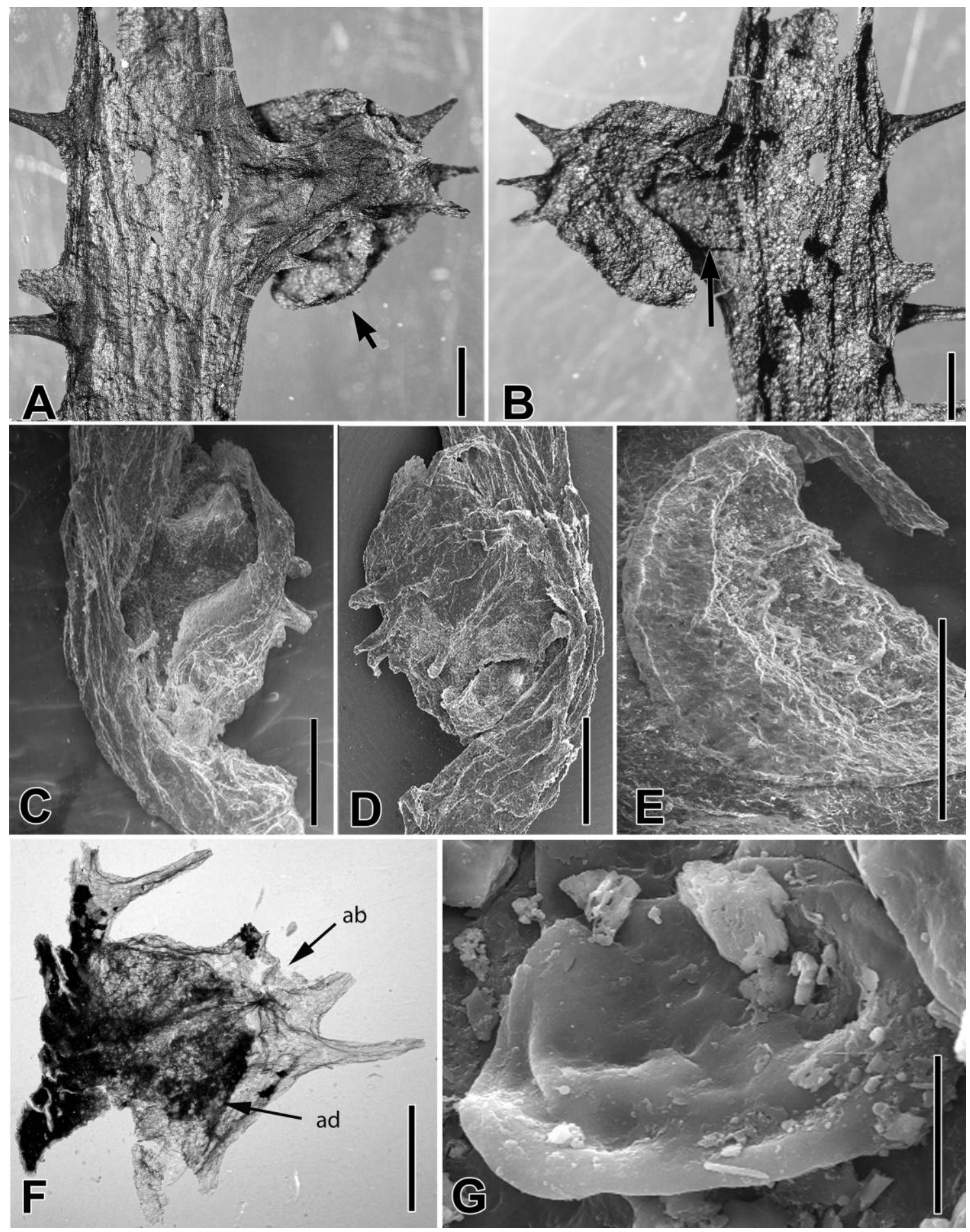

Fig. 6 Fertile specimens of Sawdonia ornata from the type locality, Cap-aux-Os, Gaspé. LM and SEM of sporangia and spore. $A$ and $B$ represented by line drawing in fig. 7. A, Specimen with stalk uppermost, sporangium folded onto stalk, mostly abaxial valve visible. Folded dehiscence margin of valve at arrow. $B$, Reverse side of $A$ showing abaxial valve folded down and covering all but a small part of the adaxial valve (arrow). A, B, GSC 138218. C, D, SEM of front and back view of sporangium oriented upright. C, Note smaller, thinner adaxial valve inside of large, spiny abaxial valve. $D$, View of surface of stalk and abaxial valve. E, SEM of folded back sporangium showing dehiscence margin (left) and part of inside of wall. F, Cleared sporangium; darker area is smaller adaxial valve (ad), lighter spiny area represents abaxial valve (ab). GSC 138219. $G$, SEM of spore adhering to sporangium wall. No trilete mark is visible. Scale bars $=10 \mathrm{~mm}(A-D, F, G), 500 \mu \mathrm{m}(E)$. 


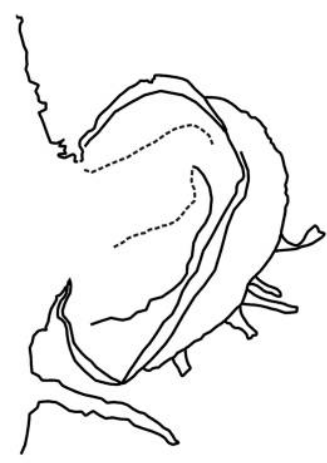

A

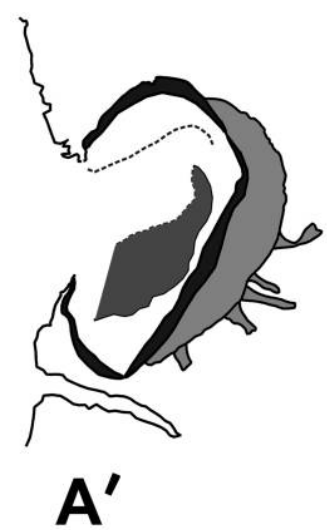

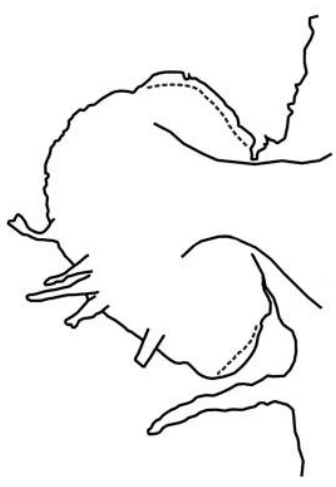

B

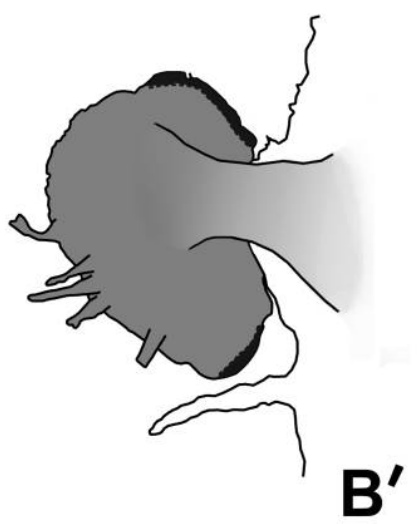

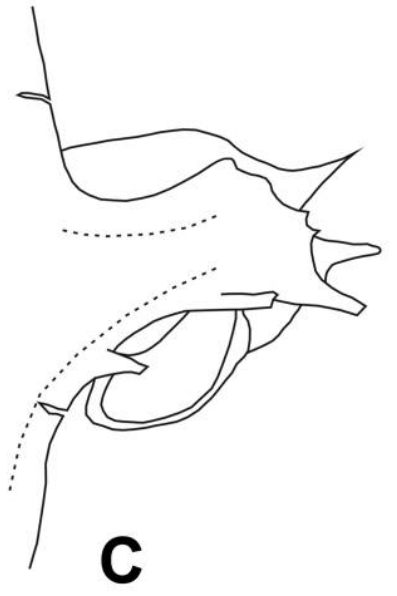
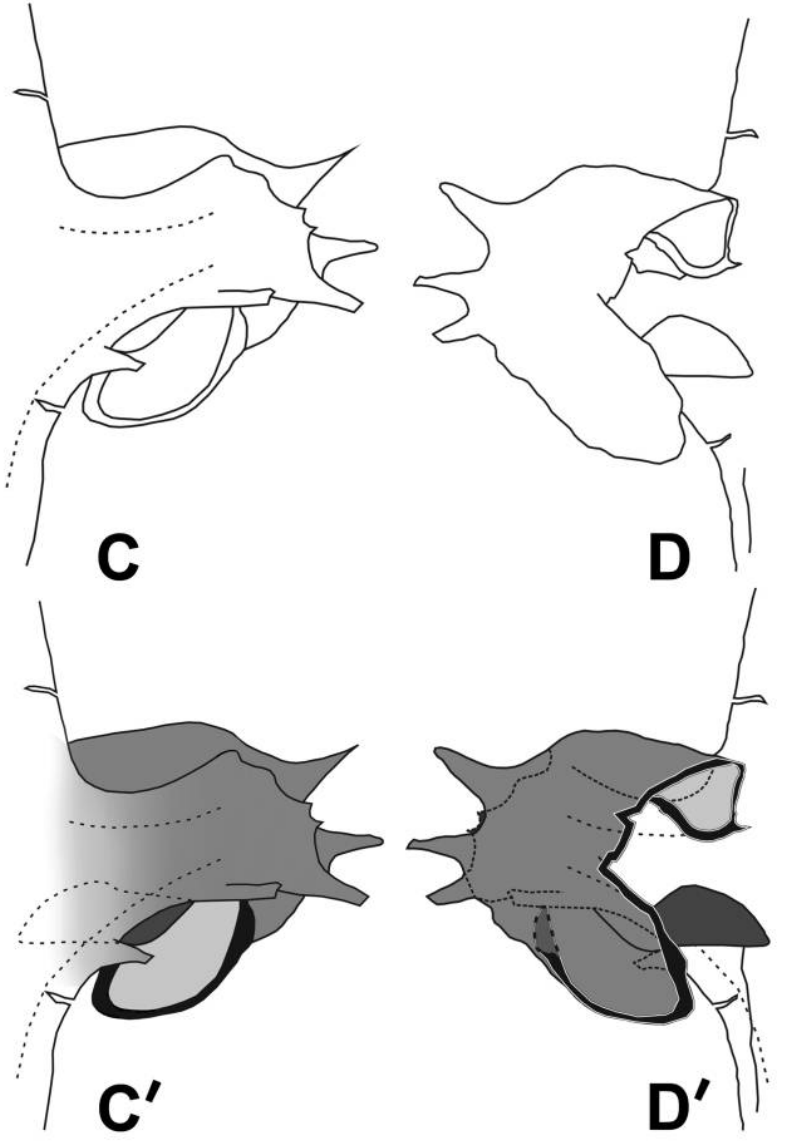

Fig. $7 A, A^{\prime}, B, B^{\prime}$, Line drawing of specimen in fig. 5. $A$ and $B$ show the two orientations. $A^{\prime}$ and $B^{\prime}$ are shaded to show different parts of sporangium. $C, D$, Line drawings of specimen in fig. $6 A$ and $6 B$. $C^{\prime}, D^{\prime}$, Drawings shaded as indicated. Shading: light gray, inside of abaxial valve; medium gray, outside of abaxial valve with spines, also stalk (where it shades to very light gray); black, dehiscence margin of abaxial valve; dark gray, adaxial valve.

In the Gaspé specimens we studied, axes are $2.2-4.4 \mathrm{~mm}$ wide, and branching occurs at intervals varying from 2 to more than $10 \mathrm{~cm}$ (fig. 8A, 8B). Lateral branches depart from the sides of main axes but are not always at the same level of rock, suggesting that they are not completely planar. Branch density differs on different individual axes such that some exhibit branching $6-10 \mathrm{~cm}$ or more apart (fig. $8 \mathrm{C}, 8 D$ ); others branch at closer intervals $(2-4 \mathrm{~cm}$; figs. 2, 9A-9C). Branching is frequently at an acute angle (fig. $8 C, 8 D$ ) but may also be more obtuse (fig. 9B). In both cases, the lateral curves upward close to the main axis. Many main axes and lateral branches have variously sized round bodies or short projections along their sides, which may be difficult to distinguish from sporangia (P. G. Gensel and C. M. Berry, personal observation; Rayner 1983; Hueber 1992) but which, on close inspection, mostly appear to be buds/arrested apices, as discussed by Rayner (1983) and Hueber (1992), or short lateral branches. A few exhibit a small projection on the lower side of one of a pair of branching axes a short distance above departure of the lateral branch, but this is rare (fig. 9B, arrow).

In some cases, such lateral bodies are small round to ovoid structures (fig. 9D-9F), and in others, one can discern tightly circinately coiled to partially uncoiled (fig. 9G, 9H) axes. The latter appear to represent undeveloped lateral branches. Interpretation of the smaller ones might include the additional possibility that some may represent immature sporangia. Mature sporangia can be definitively identified by the presence of the dehiscence margin. Spine density and length of individual spines vary among axes and fall within the size range of those previously described.

\section{Discussion}

\section{Why So Few Fertile Specimens?}

In Gaspé as well as in some other localities, remains of zosterophylls are often autochthonous or parautochthonous, and abundant sterile axes are found, with relatively few sporangiabearing ones. This is especially true for the type locality of Sawdonia ornata. Hotton et al. (2001) suggested that the zosterophylls from the Gaspé sequences were probably vegetative most of their life and that many retained the capacity for continued vegetative growth after production of sporangia. They also sug- 

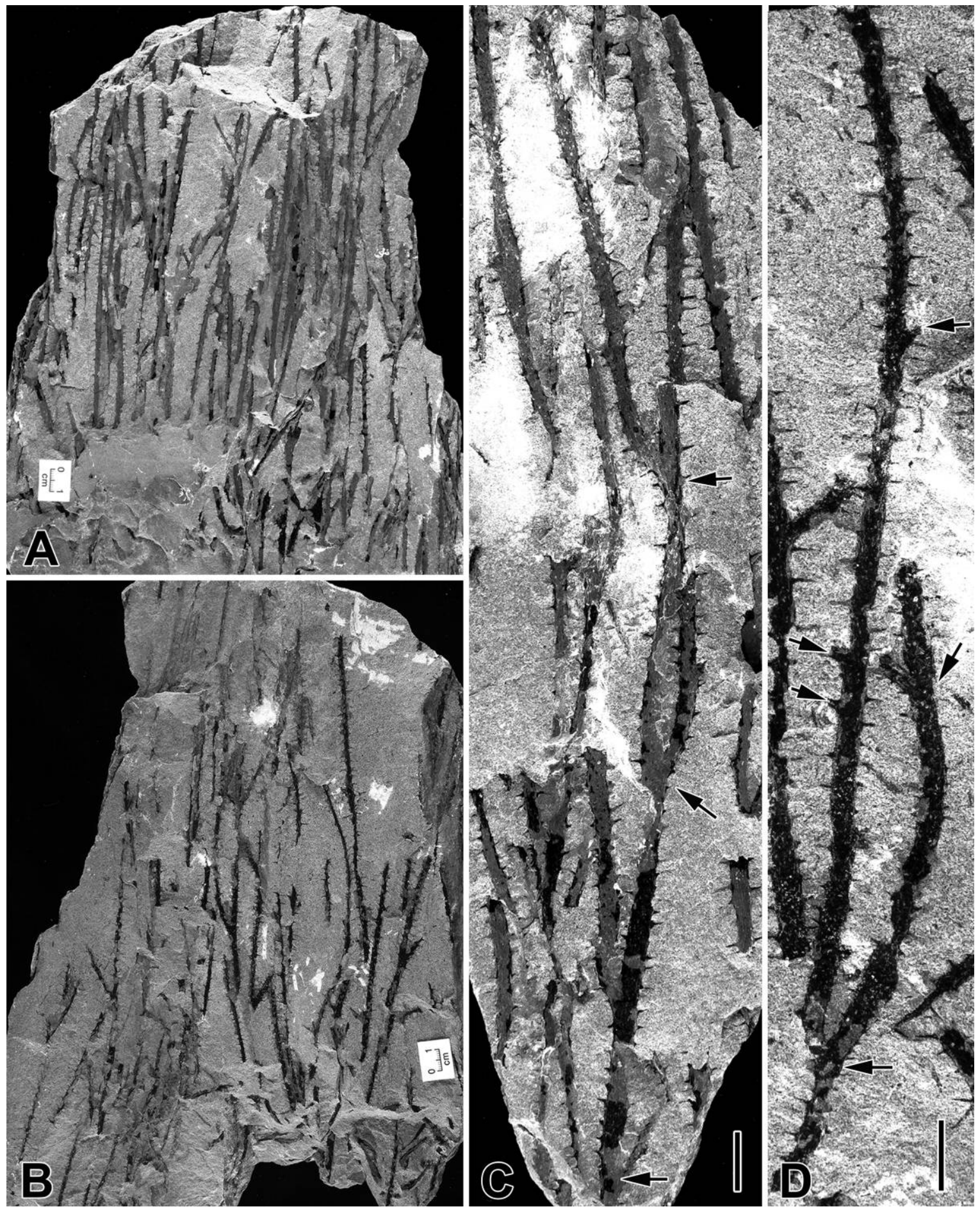

Fig. 8 Nonfertile axes of Sawdonia ornata, Gaspé. A, B, Several more or less parallel axes in matrix. These are opposite sides of the same specimen. GSC 138220. C, Part of plant showing alternate branching in nearly—but not quite- the same plane (arrows). GSC 138221. D, Both branching and possible buds (left and top right arrows). GSC 138222. Scale bars $=10 \mathrm{~mm}(C, D)$.

gest that these zosterophylls employed vegetative growth to establish large stands, which agrees with the hypothesis of Tiffney and Niklas (1985) that many early plants employed clonal growth to turf in an area. Many of these taxa also exhibit bud-like struc- tures that may represent undeveloped lateral branches, consistent with the above hypotheses. Another factor in regard to the type locality of $S$. ornata is that it was necessary to recognize some small differences that exist between sterile and fertile axes (fewer 


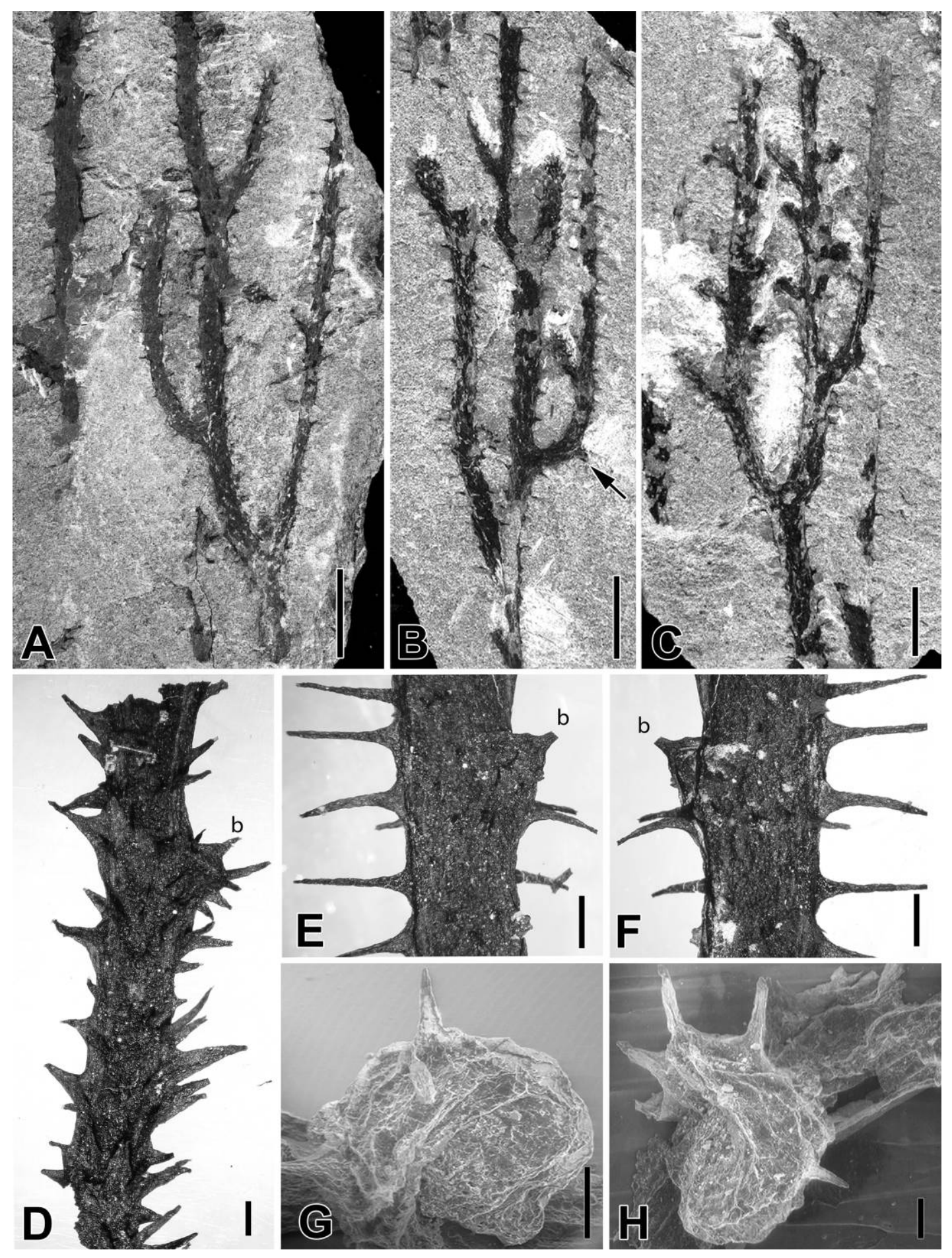

Fig. 9 Nonfertile axes of Sawdonia ornata, Gaspé. A, B. Closer views of branching, these are mostly more closely spaced than specimens in fig. 8. Note that most are at acute angle. Lateral to right in $B$ is at a broader angle, also shows possible bud at arrow. A, GSC 138223. $B$, GSC 138224. C, Closely branched specimen. Most short laterals look like either newly developed laterals or bases of incompletely preserved lateral branches. GSC 138225. D-F, Specimens from macerations. Note lateral bud with spines in $D$. $E$ and $F$ are two sides showing a very small rounded protrusion, probably a bud. D, GSC 138226. E, F, GSC 138227. G, H, SEMs showing two different stages of partially uncoiled axes. Scale bars = $10 \mathrm{~mm}(A-F), 5 \mathrm{~mm}(G, H)$. 
emergences on fertile ones); once the appropriate search image was established, several more specimens were recognized.

\section{Systematic Significance of New Data}

The newly studied specimens of $S$. ornata from the type locality demonstrate that the sporangia consist of unequal valves, that is, a larger and more rounded outer/abaxial valve-in which the stalk merges imperceptibly with the valve and both are covered with spines - and a smaller, thinner, and flat inner/ adaxial valve that lacks spines, as reconstructed in figure 10 . The dehiscence line is therefore not seen around the outline of the compressed sporangium but within it when seen from the stem looking outward. When open, each valve has a small flat dehiscence margin marking the contact between the two valves. Most of the sporangia we have examined also appear to be mature and dehisced. The whole results in an adaxially curved arrangement of the valves. Sporangia are borne laterally in subterminal regions of axes, sometimes close to the apex. They are oriented sometimes at an acute angle and sometimes perpendicular to the axis. The variable orientations may be the result of distortion because they are dehisced and dried out or from changes during transport and preservation or both.

The new data provide a more detailed view of many aspects of sporangial morphology in S. ornata and indicate that they are much more complex than previously realized. Thus, the sporangia will respond differently to even minor changes in orientation with respect to compression, resulting in the need for careful taphonomic analysis. This makes it difficult to infer original orientation. However, after careful study, we suggest that in life, sporangial stalks depart at an approximately $50^{\circ}-70^{\circ}$ angle to the axis when observed from the side but are also slightly twisted obliquely around the surface of the axis, and the sporangium is slightly curved toward the axis surface (fig. 10).

The new definitive features for this species are (1) sporangia with unequally sized valves; (2) sporangial stalks and abaxial sporangial valves covered with spiny emergences, in which the stalk extends onto the abaxial valve; (3) complex sporangial orientation both curved in toward the stem and slightly around it; and (4) variation in density and angle of lateral branching within a pseudomonopodial system. Variation in density of the spinose emergences was described by Hueber (1971), and studies of cuticular features from the type locality are as cited previously. Growth habit is inferred, as previously, to be rhizomatous.

Given that these new data are from specimens from the type locality and that the axes match in all aspects those previously described for this taxon from this locality, it is necessary to emend the generic diagnosis. We reject the information on sporangial morphology given by Hueber (1971) because the sporangia from Abitibi River have not demonstrated a larger spiny abaxial valve (Hueber 1971,1992).

Emendation. Based on Hueber 1971, with changes in italics.

\section{Sawdonia (Dawson) Hueber emend Gensel et Berry}

Stems pseudomonopodially branched, circinately tipped, unridged and spinous; spines tapered, pointed; sporangia round in abaxial view, splitting into unequal valves; larger abaxial valve more convex, smaller adaxial valve flat in lateral view, borne laterally and singly on short stalks, without subtending organs; stalk extends at least half the length of the abaxial valve, merging with it; spines occur on abaxial surface of stalk and abaxial valve. Sporangia borne in one to two rows, present in subdistal and distal regions of axes, dehiscence of sporangium transverse, basipetal, revealing inwardly folded narrow dehiscence margin on both valves, apparently homosporous; epidermal cells with cuticular papillae; stomata on stem but not on spine surfaces.

Type Species-Sawdonia ornata

Holotype. Museum specimen 3243 (Dawson 1871, pl. IX, fig. 101); Peter Redpath Museum, McGill University, Montreal, Québec, Canada. Sir William Dawson Collection.
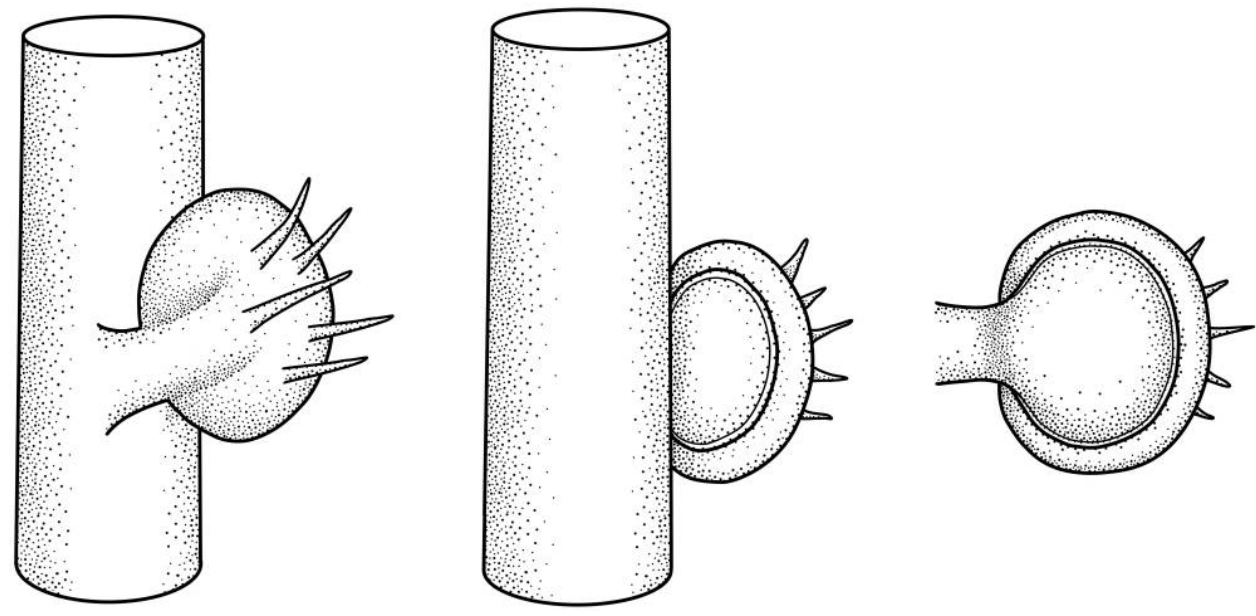

Fig. 10 Proposed reconstructions of the sporangium of Sawdonia ornata based on this study. A, Orientation and abaxial valve with stalk visible. $B$, View showing adaxial valve, folded over abaxial valve as sporangium wraps around stem. $C$, Sporangium with full view of adaxial valve, bend in stalk. 
Our discovery of the nature of the sporangia from the type locality almost $150 \mathrm{yr}$ after Dawson's first description of the fossils - a structure usually considered a key generic characteristic in zosterophylls - means that we now have to reconsider the many reported discoveries of $S$. ornata and particularly any that have previously informed emendation of the generic and specific diagnosis. Because the present discovery is unique, we reject the specific emendations of Hueber (1971) and Edwards (1983) on the basis of spiny axes in which there are no sporangia or where the sporangia do not show any details of dehiscence nor the presence of spines.

New specific diagnosis. This is based on specimens from the type locality described in this article plus cuticular features from Gaspé based on previous publications by the following: Edwards (1924), Lang (1931), Gensel et al. (1990, fig. 11B$11 D, 11 G)$, Gensel (1992, figs. 3A, 3E, 7D-7F), Edwards (1993, fig. 35). Spore and anatomical features are excluded because their provenance is unclear to us.

Sawdonia ornata (Dawson) Hueber emend. Gensel et Berry

Axes up to $4.5 \mathrm{~mm}$ wide exclusive of spines, pseudomonopodially branched. Lateral axes arranged alternately, often to two sides but not always planar, a few possessing an abaxial projection close to the branching point. Axes circinately tipped. Spines multicellular, tapered, 0.9-3.9 mm long, 0.5-1.8 $\mathrm{mm}$ broad at base, tips sometimes darkened, sometimes incomplete, sometimes flared or slightly papillate, density of distribution variable. Sporangia 1.4-3 mm wide $\times 1.4-3.4 \mathrm{~mm}$ high, stalk 1-1.5 mm wide, 1-1.5 mm long, extending onto abaxial valve; both stalk and abaxial valve with spines $0.2-0.8 \mathrm{~mm}$ long.

Epidermal cells isodiametric to elongate, elongation parallel to long axis of plant, cuticular papillae round to oval in outline, centrally located on most epidermal cells; epidermal cell size ranges from $8-20 \mu \mathrm{m}$ long $\times 4-6 \mu \mathrm{m}$ wide; stomata $8 \mu \mathrm{m}$ wide, $16 \mu \mathrm{m}$ long, elongation parallel to long axis of stem, margin of pore thickened. Rosettes consist of central often isodiametric cell with thinner, folded cuticle lacking a papilla surrounded by a radiating pattern of elongate papillate cells.

Holotype. Museum specimen 3243 (Dawson 1871, pl. IX, fig. 101); Peter Redpath Museum, McGill University, Montreal, Québec, Canada. Sir William Dawson Collection.

Epitype. Figure 5, this article. GSC 138217 (deposited in the Geological Survey of Canada collections).

\section{Comparisons}

These combined data enable clarification of similarities or differences relative to other zosterophylls. We first consider other occurrences of plants described as S. ornata or species of the genus Sawdonia and then briefly other zosterophyll taxa exhibiting both axes and sporangia bearing emergences, with the sporangia having unequal valves. A more detailed comparison of the latter will be presented in a later article.

Hueber (1964) states that his reconstruction of $S$. ornata is based on specimens from both the Gaspé type locality and Abitibi River, Ontario, considering they shared similar characters. On the basis of the reconstruction, the sporangia do not appear unequivalved or spiny, and they are oriented upright. Given the differences in type locality specimens described here, the Abitibi river specimens require reconsideration, at present better considered as an indeterminate spiny zosterophyll.

\section{Fossils Assigned to Sawdonia ornata or a Different Species of Sawdonia}

Ananiev and Stepanov (1968) described fertile remains as Psilophyton princeps in the sense used by White (1905) and Halle (1916); these specimens have been recognized as $S$. ornata (Andrews 1974; Banks et al. 1975). The majority of axes and sporangia compare reasonably well in axis diameter, emergence size and shape, sporangium and stalk sizes, and sporangium shape. No cuticular details or anatomy were available. Most sporangia are figured at a low magnification, but a few showed some details. Most of the sporangia in the Siberian specimens appear oriented at right angles to the axes, as do several of the specimens from Gaspé, where we interpreted that orientation as compression of older, probably dehisced sporangia. The authors noted the presence of a papilla on the apical portion of one sporangium. Ananiev and Stepanov (1968) state that most sporangia appear half-opened, with the valves being dislocated relative to one another and thus distorting their original shape, which they termed "irregularly rounded." They describe the presence of a narrow margin along the outer edge of each sporangium, which they interpreted as a line of dehiscence and a depression basally where the stalk attaches. The stalk is fairly obvious and not broad in their specimens. It is not possible from their images to determine whether sporangial valves are equal or unequal or whether the stalk extends onto the abaxial valve. Spores were obtained from some sporangia that are trilete and smooth walled, referable to Leiotriletes pullatus Naumova. Immature spores were also obtained, compared with Leiotriletes minutissimus. Thus, their data are similar only in some aspects with the new data from Gaspé, differing as follows: the presence of unequal valves cannot be determined with certainty, the stalk may be narrower, and it is unclear whether the stalk extends and merges with the abaxial valve. Thus, we consider that all but the specimens figured in plate II, figure 3; plate III, figures 5-7; and plate IV, figures 1 and 3 (Ananiev and Stepanov 1968) should be regarded as cf. Sawdonia. Study of original specimens is needed to determine whether they represent $S$. ornata or another taxon.

Ananiev and Stepanov (1968) figured a second group of specimens (their pl. II, fig. 3; pl. III, figs. 5-7; pl. IV, figs. 1, 3) in which axes are divided several times in short intervals and are covered by finer hair-like emergences, often very densely spaced, which reminded them of either Thursophyton or Asteroxylon (and in fact were originally named Thursophyton sibiricum [Kryshtofovich] Ananiev 1959). While Ananiev and Stepanov considered that these all represented parts of the same plant and regarded them as possibly the rhizomatous region of the plant, similar structures are not known from the type locality of $S$. ornata, and it is possible that they may represent a second type of plant. Thus, we question their relationship to the remainder of their specimens and to cf. Sawdonia sp.

Schweitzer (1979) described some specimens as S. ornata from the Pragian of Germany; the line drawings show branched axes mostly lacking emergences that may represent a rhizomatous structure. The regions interpreted as aerial shoots exhibited spine-like emergences that have a very broad base, taper sharply to a fine point, and are curved. Specimens from another 
quarry appear several times dichotomously divided, with branching and straight spines reminiscent of Psilophyton rather than Sawdonia. No fertile specimens were found. These specimens do not demonstrate the characters of the genus Sawdonia and they should be placed in another taxon.

Sawdonia spinossissima Schweitzer (1982), from the Emsian of the Eifel region (Steinbruch Koppen bei Waxweiler, Klerf Sandstone, upper Lower Emsian), also may not be appropriately assigned to the genus Sawdonia. Branching is very different from that of $S$. ornata in that lateral branches are significantly smaller than main axes and divide frequently and no photographic images of sporangia were shown. The specimens as described more closely resemble Margophyton Zakharova 1981 (formerly Psilophyton goldschmidtii). We presently doubt it represents a species of Sawdonia because of the very different branching pattern and lack of definitive data about sporangia.

Rayner (1983) described specimens from several localities of the Strathmore Group, Midland Valley, Scotland, as S. ornata. Aspects of branching, cuticle, and anatomy compare with Gaspé material to some extent. Several fertile specimens show sporangia near their apparent tips often in two rows but alternately to subalternately arranged (but appearing subopposite in his interpretive reconstruction). Rayner describes sporangia as being oval to round and lacking spines. It is unclear whether sporangial valves are equal or unequal because of the very poor preservation of the sporangia. Stalks are described as broad for some specimens where they are visible. Most are preserved in a coarsegrained sediment, so some morphological details are lacking. He also presented details about branching (pseudomonopodial, with some H-branching; branching planar, most laterals with an abaxial projection close to branching point) and provided details of cuticles and anatomy. Cuticular features compare well with those of $S$. ornata from Gaspé, except for the presence of striations on the cuticles in the Scottish material (Edwards et al. 1982; Edwards 1983). Much more information was provided about anatomy; axes exhibit a very elongate-oval stele, with branching departing from each end, and all tracheids are described as having annular thickenings with interconnecting bars, thus differing from Hueber's diagnosis in which tracheids are described as having annular, helical, or scalariform thickenings. Once again, the source of permineralized remains (Abitibi River or Gaspé) for Hueber's diagnosis is not known.

Given the ambiguity concerning sporangial morphology and some of the differences and/or ambiguities in cuticular, sporangial, and tracheid wall patterns, these specimens should be regarded as cf. Sawdonia sp. until further information about these features can be obtained. This has implications in regard to using cuticular features to recognize the genus and species $S$. ornata on the basis of isolated cuticles or vegetative axes with cuticle (Zdebska 1972; Chaloner et al. 1978).

Hueber and Grierson (1961) described apparently sterile axes with spines and cuticular features that compare well with $S$. ornata, under the name $P$. princeps as it was being used at that time, from the late Givetian or earliest Frasnian (Traverse and Schuyler 1994) Onteora Formation of South Mountain, New York, extending the range of this taxon considerably. The cuticular features match well with material from the type locality, as noted in their article, except that, according to the authors, the epidermal cells are shorter, and neither papillae nor hair bases (rosettes) were present. No sporangia were found.
At present, it is unclear-in the absence of sporangial details and possibly because of the differences in cuticular features - whether these remains should still be considered referable to $S$. ornata, as circumscribed in this article. Again, we suggest that they be referred to cf. Sawdonia sp.

Sawdonia acanthotheca, described from the Emsian Campbellton Formation of northern New Brunswick by Gensel et al. (1975), has axes covered with emergences of variable shapes. The cuticle, while showing spines of variable shapes and dimensions (some very deltoid, others more conical, some divided), is not well enough preserved to exhibit all epidermal features; rosette cells and stomata have not been found. Sporangia in $S$. acanthotheca are much larger than those of $S$. ornata and clearly globose in abaxial view. The abaxial valve possesses spines similar to some borne on the main axes but are much shorter. Sporangia in $S$. acanthotheca were described having valves that are equal to slightly unequal in size; examination of new transfer specimens and reexamination of earlier preparations confirms this. In many specimens, both valves are slightly rounded, with the abaxial one perhaps being slightly more rounded than the adaxial one. Sporangia and axes of $S$. acanthotheca are larger than in S. ornata, and a variety of spine morphologies present on axes and sporangia continues to distinguish the two taxa. We conclude, on the basis of the new data presented above, that these plants represent a different taxon, and it will be renamed in a later publication.

Specimens described as Sawdonia curstipa by Wang and Hao (1996) from the Middle Devonian of Xinjiang, China, have been re-examined by Xu et al. (2011). They considered that most of the specimens assigned to this taxon represent Serrulacaulis cf. $S$. furcatus (Xu et al. 2011), on the basis of the distinctive morphology of emergences, and that the remaining specimens are too poorly preserved to be identifiable.

\section{Other Genera of Zosterophylls}

Other zosterophyll genera differ in details of emergence type and/or in having equivalved sporangia. For example, Serrulacaulis spineus (Xu et al. 2011) but not S. furcatus (Hueber et Banks 1979 emend Berry et Edwards 1994), possibly Trichopherophyton teuchansii Lyon et Edwards 1991; Edwards 2004), and Crenaticaulis verruculosus Banks et Davis (1969) all differ in details of emergence type, how emergences are arranged on axes, or organization of sporangial valves or dehiscence region. Serrulacaulis furcatus from the lower Upper Devonian of New York (Hueber and Banks 1979) should be re-evaluated in terms of whether sporangial valves are equal or unequal, in light of the folding over of the abaxial valve shown in plate $\mathrm{V}$, figure 1 of their article.

The genus most similar to our revised understanding of S. ornata is Ensivalia deblondii, described by Gerrienne (1996) from the Early Devonian of Ensival, Belgium. Ensivalia exhibits similarly shaped emergences on axes and the abaxial valve of the laterally borne sporangia, which also is larger than the adaxial valve. Gerrienne (1996) discussed how similar to S. ornata this Belgian plant is but kept it as a separate taxon because it was then thought that $S$. ornata sporangia possessed two equal valves. In light of the new data, sporangia are more similar, but a remaining significant difference is that in Ensivalia, the sporangial 
stalk appears slightly longer and more robust and consistently turns upward so that sporangia are borne in an upright fashion. Sporangia are mainly along one side of the axes, but sometimes two are closely spaced and oriented at $90^{\circ}$ to each other. We consider that Ensivalia is similar enough to be placed in the genus Sawdonia as a distinct species, and P. Gerrienne (personal communication, November 2014). We thus create a new combination for this taxon as follows.

Sawdonia deblondii (Gerrienne) Gensel et Berry comb. nov.

Basionym. Ensivalia deblondii, Gerrienne 1996, Académie Royale de Belgique Classe des Sciences (p. 35-36). Differences are stated above.

\section{Conclusions}

New specimens of both vegetative and fertile axes of Sawdonia ornata from the type locality in Gaspé are figured and described. Several axes, apparently lacking sporangia, demonstrate variation in branching density and pattern and the occurrence of buds or partially developed lateral branches, as well as variation in emergence length and density. While these are consistent with earlier descriptions or illustrations of this taxon (although not always clearly those from the type locality), study of fertile specimens from the type locality has provided new data about sporangia and sporangial stalks. Key to obtaining more data about the nature of the sporangium and its stalk is information revealed by maceration and study with LM and SEM. As a result of these new data, a clear set of characters is documented, and an emended diagnosis is presented. Several taxa referred to either S. ornata or other species of Sawdonia are excluded from it.

This circumscribed concept of both the genus Sawdonia and species ornata may result in establishing new taxa for at least superficially similar-looking plants or plants that still present some but not all critical characters after careful study. We considered the alternative, namely, expanding only the generic concept of Sawdonia to include equi- and unequivalved sporangia and simply emending the species diagnosis. A reason for doing this would be that it is not always possible to determine whether sporangial valves are equal or unequal, spiny or not, and relative position of stalk versus sporangium, on less well-preserved specimens that have been identified as $S$. ornata because it is often provable only after maceration. However, this would result in unrelated plants being included in one species and valuable information about diversity being lost. In regard to vegetative axes with morphology and/or cuticular features classically considered typical of $S$. ornata, it is currently unclear whether the suite of characters currently considered to be distinctive for $S$. ornata - as described in previous diagnoses based on plants from at least three localities, most of which are present in specimens from the type locality-occur only in that taxon. We will consider these ramifications further in a future article.

\section{Acknowledgments}

We acknowledge an award from Cardiff University Distinguished Visiting Fellows Scheme (to P. G. Gensel) and Cardiff University School of Earth and Ocean Sciences research study leave (to C. M. Berry) that made this collaboration possible. A University of North Carolina research leave to P. G. Gensel is also acknowledged. C. M. Berry acknowledges Natural Environment Research Council grant NE/J007897/1 for travel to the United States. Susan Whitfield is thanked for preparation of some of the line drawings. We are grateful to Leonid Popov for providing some Russian translation.

\section{Literature Cited}

Ananiev AR 1959 The most important localities of Devonian flora in the Sayan-Altay mountain region. Tomsk University Press, Tomsk. Ananiev AR, SA Stepanov 1968 Finds of sporiferous organs in Psilophyton princeps Dawson emend. Halle in the Lower Devonian of the southern Minusinsk Trough, Western Siberia. Pages 30-46 in New materials on the stratigraphy and paleontology of the Lower and Middle Paleozoic of Western Siberia. Tomsk State Univ Trudy 202.

Andrews HN 197425 years of botany: paleobotany 1947-1972. Ann Mo Bot Gard 61:179-202.

Banks HP 1968 The early history of land plants. Pages 73-107 in ET Drake, ed. Evolution and environment. Yale University Press, New Haven, CT.

1975 Reclassification of Psilophyta. Taxon 24:401-13.

Banks HP, MR Davis 1969 Crenaticaulis, a new genus of Devonian plants allied to Zosterophyllum, and its bearing on the classification of early land plants. Am I Bot 56:436-449.

Banks HP, FM Hueber, S Leclercq 1975 Anatomy and morphology of Psilophyton dawsoni, sp. n. from the late Lower Devonian of Quebec (Gaspé), and Ontario, Canada. Palaeontogr Am 8:77-127.

Berry CM, D Edwards 1994 New data on the morphology and anatomy of the Devonian zosterophyll Serrulacaulis Hueber and Banks from Venezuela. Rev Palaeobot Palvnol 81:141-150.

Chaloner WG, A Hill, ECW Rogerson 1978 Early Devonian plant fossils from a southern England borehole. Palaeontology 21:693-707.
Dawson JW 1871 The fossil plants of the Devonian and Upper Silurian formations of Canada. Geol Surv Can 1:1-92.

Edwards D 1993 Cells and tissues in the vegetative sporophytes of early land plants. New Phytol 125:225-247.

2004 Embryophytic sporophytes in the Rhynie and Windyfield cherts. Trans R Soc Edinb Earth Sci 94:397-410.

Edwards D, DS Edwards, RJ Rayner 1982 The cuticle of early vascular plants and its evolutionary significance. Pages 341-362 in DR Cutler, KL Alvin, CE Price, eds. The plant cuticle. Academic Press, London.

Edwards D, H Kerp, H Hass 1998 Stomata in early land plants: an anatomical and ecophysiological approach. LExp Bot 49:255278.

Edwards DS 1983 New observations on Sawdonia ornata from Scotland. Trans R Soc Edinb Earth Sci 74:79-93.

Edwards WN 1924 On the cuticular structure of the Devonian plant Psilophyton. LLinn Soc Bot Lond 46:377-385.

Fairon-Demaret M, J Hilton, CM Berry 1999 Surface preparation of macrofossils (dégagement). Pages 33-35 in TP Jones, NP Rowe, eds. Fossil plants and spores: modern techniques. Geological Society, London.

Gensel PG 1992 Phylogenetic relationships of the zosterophylls and lycopsids: evidence from morphology, paleoecology, and cladistic methods of inference. Ann Mo Bot Gard 79:450-473. 
Gensel PG, HN Andrews 1984 Plant life in the Devonian. Praeger, New York.

Gensel PG, HN Andrews, WH Forbes 1975 A new species of Sawdonia with notes on the origin of microphylls and lateral sporangia. Bot Gaz 136:50-62.

Gensel PG, NG Johnson, PK Strother 1990 Early land plant debris (Hooker's "Waifs and Stravs"). Palaios 5:520-547.

Gerrienne P 1996 Contribution à l'étude paléobotanique du Dévonien inférieur de Belgique: les genres nouveaux Ensivalia et Faironella. Académie Royale de Belgique, Brussels.

Griffing DH, JS Bridge, CL Hotton 2000 Coastal-fluvial palaeoenvironments and plant palaeoecology of the Lower Devonian (Emsian), Gaspé Bay, Quebec, Canada. Pages 61-84 in PF Friend, BPJ Williams, eds. New perspectives on the Old Red Sandstone. Geol Soc Lond Spec Publ 180.

Halle 1916 Lower Devonian plants from Röragen in Norway. K Sven Vetenskapakad Handl 57:1-46.

Hotton CL, FM Hueber, DH Griffing, JS Bridge 2001 Early terrestrial plant environments: an example from the Emsian of Gaspé, Canada. Pages 179-212 in PG Gensel, D Edwards, eds. Plants invade the land: evolutionary and environmental perspectives. Columbia University Press, New York.

Hueber FM 1964 The Psilophytes and their relationship to the origin of ferns. Torrey Bot Club Mem 21:5-9.

1971 Sawdonia ornata: a new name for Psilophyton princeps var. ornatum. Taxon 20:641-642.

1992 Thoughts on the early lycopsids and zosterophylls. Ann Mo Bot Gard 70:474-499.

Hueber FM, HP Banks 1967 Psilophyton princeps: the search for organic connection. Taxon 16:81-85.

1979 Serrulacaulis furcatus gen et sp nov, a new zosterophyll from the lower Upper Devonian of New York State. $\underline{\text { Rev Palaeobot }}$ Palvnol 28:169-189.

Hueber FM, JD Grierson 1961 On the occurrence of Psilophyton princeps in the early Upper Devonian of New York. Am IBot 48:473-479.

Kenrick P, PR Crane 1997 The origin and early diversification of land plants: a cladistic study. Smithsonian Institution Press, Washington, DC.

Lang WH 1931 On the spines, sporangia and spores of Psilophyton princeps Dawson shown in specimens from Gaspé. Philos Trans R Soc B 219:421-442.
1932 Contributions to the study of the Old Red Sandstone flora of Scotland. VIII. On Arthrostigma, Psilophyton, and some associated plant-remains from the Strathmore beds of the Caledonian Lower Old Red Sandstone. Trans R Soc Edinb 57:491-521.

Lyon AG, D Edwards 1991 The first zosterophyll from the Lower Devonian Rhynie Chert, Aberdeenshire. Trans R Soc Edinb (Earth Sci) 82:323-332.

Rayner RJ 1983 New observations on Sawdonia ornata from Scotland. Trans R Soc Edinb 74:79-93.

Richardson JB, DC McGregor 1986 Silurian and Devonian spore zones of the Old Red Sandstone continent and adjacent regions. Geol Surv Can Bull 364:1-79.

Schweitzer H-J 1979 Die Zosterophyllaceae des rheinischen Unterdevons Bonn. Palaeobot Mitteil Univ Bonn 3:1-32.

1982 Zwei neue Pflanzen aus dem Unterdevon der Eifel. Bonn Palaeobot Mitteil Univ Bonn 9:1-15.

Smith GO, D White 1905 The geology of the Perry Basin in southeastern Maine. US Geol Surv Prof Pap 35.

Tiffney BH, KJ Niklas 1985 Clonal growth in land plants: a paleobotanical perspective. Pages 35-66 in JBC Jackson, LW Buss, RE Cook, eds. Population biology and evolution of clonal organisms. Yale University Press, New Haven, CT.

Traverse A, A Schuyler 1994 Palynostratigraphy of the Catskill and part of the Chemung Magnafacies, southern New York State, USA. Cour Forsch Senck 169:261-274.

Wang DM, SG Hao 1996 Report of Sawdonia in China-Sawdonia curstipa sp nov. Acta Bot Sin 38:318-322. (In Chinese with English abstract.)

Wellman CH, L Axe 1999 Extracting plant mesofossils and megafossils by bulk acid maceration. Pages 11-14 in RP Jones, NP Rowe, eds. Fossil plants and spores: modern techniques. Geological Society of London, Bath.

Xu H-H, CM Berry, Y Wang 2011 Morphological study on the Devonian zosterophyll Serrulacaulis Hueber and Banks: new materials and emendation. Palaeoworld 20:322-331.

Zakharova TV 1981 On the systematic position of the species 'Psilophyton' Goldschmidtii from the lower Devonian Period in Eurasia. Palaeontol J 15:109-118. (In Russian.)

Zdebska D 1972 Sawdonia ornata (=Psilophyton princeps var ornatum) from Poland. Acta Palaeobot 13:77-98. 